\title{
Hypercoagulable State dan Diabetes Melitus Tipe 2: Korelasi antara Fibrinogen dan HbA1c
}

\author{
Hery Aprijadi, Rachmat Sumantri, Trinugroho Heri, Pandji Irani, Amaylia Oehadian, Augusta \\ Y. L. Arifin \\ SubBagian Hemato-Onkologi Medik, Departemen Ilmu Penyakit Dalam Fakultas Kedokteran \\ Universitas Padjadjaran/Rumah Sakit Dr. Hasan Sadikin Bandung
}

\begin{abstract}
Abstrak
Hiperkoagulabilitas merupakan penyebab kelainan vaskular pada diabetes melitus tipe 2 (DM tipe 2). Fibrinogen merupakan petanda hiperkoagulabilitas akibat inflamasi sistemik. Kadar HbA1c dipakai untuk menilai kadar gula darah jangka panjang dan berhubungan dengan petanda inflamasi. Terdapat perbedaan hasil penelitian terdahulu tentang bagaimana hubungan antara kadar fibrinogen dan HbAlc. Ada yang menyatakan hubungan bermakna dan ada pula yang tidak. Tujuan penelitian ini untuk melihat adakah korelasi antara fibrinogen dan HbA1c. Penelitian ini merupakan penelitian potong lintang pada penderita rawat jalan DM tipe 2 di RS Dr. Hasan Sadikin Bandung selama Januari-Juli 2010. Kriteria inklusi penderita DM tipe 2 yang baru didiagnosis, normotensi, kadar hemoglobin normal, serta tes fungsi hati dan ginjal normal. Dilakukan pemeriksaan kadar fibrinogen, trigliserida, dan HbA1c. Kriteria eksklusi yaitu mendapat obat antiagregasi trombosit, obat antidiabetik oral, atau menderita penyakit autoimun. Analisis statistik berupa Spearman dan regresi digunakan pada penelitian ini. Terdapat 63 subjek yang diikutkan dalam penelitian. Semua subjek memiliki kadar HbA1c lebih dari 6,5\% (rata-rata 8,21 $\pm 2,5 \%$ ). Terdapat 33 penderita $(53 \%)$ dengan kadar fibrinogen di atas harga normal (rata-rata $416,75 \pm 102,7 \mathrm{mg} / \mathrm{dL})$. Tidak terdapat korelasi yang bermakna antara kadar fibrinogen dan HbA1c. Simpulan, tidak terdapat korelasi antara kadar fibrinogen dan HbAlc. Meskipun demikian subjek dengan diabetes melitus cenderung mempunyai kadar fibrinogen yang tinggi. [MKB. 2014;46(1):48-51]
\end{abstract}

Kata kunci: Diabetes melitus tipe 2, fibrinogen, HbA1c, hypercoagulable state

\section{Hypercoagulable State and Type 2 Diabetes Mellitus: the Correlation between Fibrinogen and HbA1c}

\begin{abstract}
Hypercoagulability has been suggested as a result of type 2 diabetic mellitus vascular disease. Fibrinogen is a marker of hypercoagulability due to systemic inflammation. HbAlc level is used to measure long-term blood glucose level. There was inconsistent findings about the correlation between fibrinogen level and HbA1c. Previous study found a significant correlation between fibrinogen levels and HbAlc, while other study showed different results for this finding. The aim of this study was to determine the correlation between fibrinogen and HbAlc. A cross-sectional study was performed in outpatients type 2 diabetes mellitus (DM) in Dr. Hasan Sadikin General Hospital Bandung during January-July 2010. Patients with newly diagnosed type 2 DM, normotension, normal hemoglobin level, normal liver function test and normal kidney function test were included in this study. Fibrinogen, trigliseride, and HbAlc levels were examined. The exclusion criteria were patients taking antiplatelet drugs or oral antidiabetic and had autoimmune diseases. Spearman and regression analysis were used in this study. Sixty three subjects were included in this study. All subjects had HbA1c level more than 6.5\% (mean 8.21 $\pm 2.5 \%$ ). Thirty three patients $(53 \%)$ had fibrinogen level of more than the normal limit (mean $416.75 \pm 102.7 \mathrm{mg} / \mathrm{dL}$ ). The mean of trigliseride level was $235.32 \pm 131.3 \mathrm{mg} / \mathrm{dL}$. No significant correlation between fibrinogen and HbA1c. In conclusion, there is no correlation between the fibrinogen levels and HbAlc. However, subjects with diabetes mellitus tend to have high fibrinogen levels. [MKB. 2014;46(1):48-51]
\end{abstract}

Key words: Fibrinogen, HbA1c, hypercoagulable state, type 2 diabetes mellitus

Korespondensi: Hery Aprijadi, dr., Sp.PD, Departemen Ilmu Penyakit Dalam Fakultas Kedokteran Universitas Padjadjaran/ Rumah Sakit Hasan Sadikin Bandung, mobile 081540914888 e-mail heryaprijadi@yahoo.com 


\section{Pendahuluan}

Hiperkoagulasi merupakan gangguan koagulasi darah, yaitu pergeseran keseimbangan hemostatik akibat peningkatan faktor prokoagulan. Hal ini cenderung akan menyebabkan suatu trombus. ${ }^{1-3}$

Diabetes melitus (DM) tipe 2 (dua) merupakan penyakit dengan morbiditas dan mortalitas yang terus meningkat di dunia. Perubahan aktivitas fisik dan diet berperan penting dalam perkembangan penyakit ini. Beberapa perubahan hematologi abnormal terjadi pada diabetes melitus (DM). Pada penderita DM tipe 2 kondisi hiperkoagulabilitas sering ditemukan dan berperan dalam terjadinya makroangiopati. HbA1c dipakai untuk menilai kadar gula dalam darah jangka panjang. Penderita $\mathrm{DM}$ dengan $\mathrm{HbA} 1 \mathrm{c} \leq 7 \%$ cenderung akan lebih rendah kemungkinan terkena angina rekuren. ${ }^{4}$ Hiperkoagulabilitas ini dianggap sebagai akibat kelainan vaskular pada penderita DM.

Diabetes melitus juga berhubungan dengan peningkatan kadar petanda inflamasi sistemik subklinis, akan tetapi sedikit data yang mengaitkan antara $\mathrm{HbAlc}$ dan petanda inflamasi. Fibrinogen merupakan glikoprotein yang dapat larut dalam plasma yang dihasilkan oleh hati dan kadarnya meningkat pada keadaan inflamasi. Fibrinogen sangat penting di berbagai proses aterotrombosis, hemostasis, agregasi trombosit, dan viskositas darah. Penelitian telah memperlihatkan bahwa peningkatan konsentrasi fibrinogen merupakan salah satu faktor risiko penyakit kardiovaskular pada penderita DM, selain dipengaruhi oleh faktor genetik dan lingkungan. Fibrinogen yang meningkat juga berkorelasi dengan pembentukan trombin yang meningkat. Peningkatan fibrinogen dan aktivitas prokoagulan disertai penurunan kapasitas fibrinolisis pada penderita DM tipe 2 dianggap berperan penting di dalam patogenesis aterosklerosis. $^{3}$

Hubungan kadar fibrinogen dengan hiperglikemia masih bersifat kontroversial. Soliman ${ }^{5}$ menunjukkan korelasi yang signifikan antara kadar fibrinogen dan HbAlc. Data menunjukkan bahwa perbaikan gula darah akan menurunkan kadar fibrinogen, namun pada penelitian lain, Gustavsson dan Agardh ${ }^{6}$ memperlihatkan tidak terdapat korelasi antara fibrinogen dan HbAlc. Tujuan penelitian ini untuk mengevaluasi adakah hubungan antara fibrinogen dan $\mathrm{HbAlc}$ pada penderita DM tipe 2.

\section{Metode}

Penelitian ini merupakan suatu penelitian potong lintang. Untuk melihat hubungan antara kadar fibrinogen dan $\mathrm{HbA} 1 \mathrm{c}$ digunakan analisis statistik berupa Korelasi Spearman. Untuk dapat melihat besarnya pengaruh kadar fibrinogen pada $\mathrm{HbA} 1 \mathrm{c}$ digunakan regresi linier dan nonlinier.

Penelitian ini dilakukan di divisi HematologiOnkologi Medik Departemen Ilmu Penyakit Dalam mulai bulan Januari-Juli 2010. Subjek penelitian yaitu penderita rawat jalan di poliklinik Endokrinologi RS Dr. Hasan Sadikin Bandung. Kriteria inklusi penderita DM tipe 2 yang baru didiagnosis, kadar $\mathrm{Hb}>14 \mathrm{~g} / \mathrm{dL}$ (pria) dan $>12 \mathrm{~g} /$ dL (wanita), normotensi, fungsi hati dan ginjal normal, dan juga tidak hamil. Kriteria eksklusi yaitu sedang dapat obat antiagregasi trombosit, antidiabetik oral dalam tiga bulan terakhir, atau menderita penyakit autoimun. Kadar fibrinogen, HbA1c, dan trigliserida diperiksa pada semua subjek di laboratorium Patologi Klinik RS Dr. Hasan Sadikin Bandung. Tes HbA1c didasarkan penangkapan glukosa oleh hemoglobin dalam eritrosit yang secara konstan bertahan dalam 3 bulan sehingga nilainya tidak dipengaruhi kadar gula darah harian.

\section{Hasil}

Subjek penelitian ini sebanyak 63 orang, terdiri atas 31 pria dan 32 wanita. Kadar hemoglobin rata-rata untuk pria $14,2 \pm 0,2 \mathrm{~g} / \mathrm{dL}$ dan wanita $12,4 \pm 0,4 \mathrm{~g} / \mathrm{dL}$ (Tabel 1).

Terdapat 33 penderita (53\%) mempunyai kadar fibrinogen $>$ nilai normal (rata-rata 416,75 $\pm 102,7$ $\mathrm{g} / \mathrm{dL}$ ). Kadar trigliserida rata-rata $235,32 \pm 131,3$ $\mathrm{g} / \mathrm{dL}$. Semua penderita mempunyai kadar HbA1c $>6,5 \%$ (rata-rata $8,21 \pm 2,5 \%$ ) yang dapat dilihat pada Tabel 2.

Berdasarkan pengujian Korelasi Spearman tidak ditemukan hubungan signifikan antara kadar fibrinogen dan HbA1c $(r=-0,0029 ; p=+0,823)$. Pengujian lain dilakukan melalui analisis regresi, baik secara linier maupun nonlinier (logaritmik)

\section{Tabel 1 Karakteristik Dasar Subjek Penelitian}

\begin{tabular}{lcc}
\hline & $\begin{array}{c}\text { Laki-laki } \\
(\mathbf{n}=\mathbf{3 1}) \\
\text { Rata-rata (SD) }\end{array}$ & $\begin{array}{c}\text { Perempuan } \\
(\mathbf{n = 3 2}) \\
\text { Rata-rata } \\
\text { (SD) }\end{array}$ \\
\hline $\begin{array}{l}\text { Usia (tahun) } \\
\begin{array}{l}\text { Hemoglobin } \\
\text { (g/dL) }\end{array}\end{array}$ & 58 & 57 \\
$\begin{array}{l}\text { Tekanan darah } \\
\text { sistol (mmHg) }\end{array}$ & $140(10)$ & $12,4(0,4)$ \\
$\begin{array}{l}\text { Tekanan darah } \\
\text { diastol(mmHg) }\end{array}$ & $80(10)$ & $80(10)$ \\
\hline
\end{tabular}


Tabel 2 Kadar Trigliserida, Fibrinogen, dan HbA1c Subjek Penelitian

\begin{tabular}{lcc}
\hline & $\begin{array}{c}\text { Laki-laki } \\
(\mathbf{n}=31) \\
\text { Rata-rata }(\text { SD) }\end{array}$ & $\begin{array}{c}\text { Perempuan } \\
(\mathbf{n}=32) \\
\text { Rata-rata (SD) }\end{array}$ \\
\hline $\begin{array}{l}\text { Trigliserida } \\
(\mathrm{mg} / \mathrm{dL})\end{array}$ & 63 & $235,32(245,79)$ \\
$\begin{array}{l}\text { Fibrinogen } \\
(\mathrm{mg} / \mathrm{dL})\end{array}$ & 63 & $416,75(96,68)$ \\
HbA1c $(\%)$ & 63 & $8,21(1,72)$ \\
\hline
\end{tabular}

juga tidak ditemukan hubungan yang signifikan antara keduanya $(\mathrm{p}=0,593$ dan $\mathrm{p}=0,654)$.

\section{Pembahasan}

Fibrinogen termasuk protein fase akut yang sangat berperan terhadap risiko penyakit kardiovaskular. Mekanisme regulasi fibrinogen pada manusia belum dapat dimengerti sepenuhnya. Fibrinogen plasma umumnya meningkat pada DM tipe 2 sehingga dianggap bahwa hiperfibrinogenemia berhubungan dengan morbiditas dan mortalitas yang tinggi pada penyakit ini. Keadaan ini juga ditunjang penelitian yang menunjukkan peranan insulin menurunkan kadar fibrinogen plasma. ${ }^{7}$

Viskositasplasmamemilikihubunganlangsung dengan konsentrasi plasma total. Protein plasma utama adalah fibrinogen, globulin, dan albumin. Fibrinogen mempunyai efek positif paling besar terhadap viskositas plasma dibandingkan dengan globulin dan albumin. Peningkatan viskositas plasma akibat peningkatan konsentrasi fibrinogen berperan di dalam peningkatan viskositas darah pada DM. Hiperviskositas merupakan komponen penting kelainan mikrosirkulasi pada DM. ${ }^{8}$

Penelitian ini membuktikan tidak terdapat korelasi yang bermakna antara kadar fibrinogen dan $\mathrm{HbA} 1 \mathrm{c}$ pada penderita DM tipe 2. Keadaan ini kemungkinan terjadi oleh karena perbedaan kadar $\mathrm{HbA} 1 \mathrm{c}$ pada berbagai penelitian. King dkk. ${ }^{9}$ menyatakan bahwa kejadian inflamasi meningkat hanya jika kadar HbA1c di atas $9 \%$. Pada penelitian ini kadar HbAlc hanya 8,21\%. Selain itu, faktor-faktor yang memengaruhi kadar fibrinogen misalnya usia, indeks massa tubuh, merokok, aktivitas fisik, dan penyakit jantung koroner tampaknya juga harus dipertimbangkan dalam penelitian ini. Namun demikian, penderita DM cenderung mempunyai kadar fibrinogen di atas nilai normal.

Kadar trigliserida darah dapat memengaruhi kadarHbA1c,sedangkanpada hipertrigliseridemia dapat menurunkan kadar HbA1c, ${ }^{9}$ oleh karena itu kadar trigliserida diperiksa pada penelitian ini.
Kadar trigliserida plasma cenderung meningkat pada penderita DM tipe 2. Mekanisme yang bertanggung jawab pada peningkatan trigliserida yaitu sekresi very low density lipoprotein (VLDL) oleh hati dan pembersihan triacylglycerol yang terlambat. Hipertrigliseridemia biasanya disertai penurunan kolesterol high density lipoprotein (HDL) yang merupakan gambaran yang sering ditemukan pada penderita DM. ${ }^{8}$

Simpulan, tidak didapatkannya korelasi kadar fibrinogen dengan $\mathrm{HbAlc}$ pada penderita DM tipe 2. Penderita DM cenderung memiliki kadar fibrinogen yang tinggi yang berkaitan erat dengan terjadinya trombosis.

\section{Daftar Pustaka}

1. Remkova A. Diagnostic approach to hypercoagulable states. Bratisl Lek Listy. 2006;107:292-5.

2. Spronk HM, van der Voort D, Ten Cate $\mathrm{H}$. Blood coagulation and the risk of atherothrombosis: a complex relationship. Throm J. 2004;2(1):12.

3. Stegenga ME, van der Crabben SN, Blumer RM, Levi M, Meijers JC, Serlie MJ, dkk. Hyperglicemia enhances coagulation and reduces neutrophil degradation, whereas hyperinsulinemia inhibits fibrinolysis during human endotoxemia. Blood. 2008;112:82-9.

4. Corpus RA, George PB, House JA, Dixon SR, Ajluni SC, Devlin WH, dkk. Optimal glycemic control is associated with a lower rate of target vessel revascularization in treated type II diabetic patients undergoing elective percutaneous coronary intervention. J Am Coll Cardiol. 2004;43(1):8-14.

5. Soliman GZ. Abnormalities in plasma concentration of lipids and fibrinogen of Egyptian microalbuminuric NIDDM type 2 diabetic patients. Egypt J Hosp Med. 2005;21:66-81.

6. Gustavsson CG, Agardh CD. Markers of inflammation in patients with coronary artery disease are also associated with glycosylated haemoglobin A1c within the normal range. Eur Heart J. 2004;25(3):2120-4.

7. Barazzoni R, Kiwanuka E, Zaneti M, Cristini $M$, Vettore $M$, Tessari P. Insulin acutely increases fibrinogen production in individuals with type 2 diabetes but not in individuals without diabetes. Diabetes. 2003;52(7):1851-6.

8. Khan TM, Marwat MA, Khan P, Wazir $\mathrm{F}$, Rehman A. Plasma fibrinogen level in diabetics with complications-a prospective study. Gomal J Med Sci. 2005;3(2):48-50. 
9. King DE, Buchanan TA, Mainous AG, Pearson WS. C-reactive protein and glycemic control in adults with diabetes. Diabetes Care. 2003;26:1535-9.

10. Garrib A, Griffiths W, Eldridge P, Hatton
R, Wosley A, Crook M. Artefactually low glycated haemoglobin in a patient with severe hypertrigliseridaemia. J Clin Pathol. 2003;56(5):394-5. 